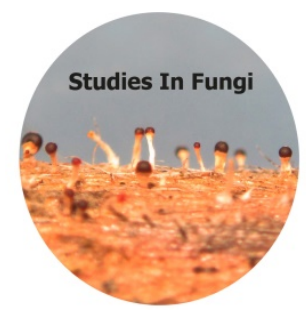

Studies in Fungi 5(1): 517-525 (2020) www.studiesinfungi.org ISSN 2465-4973

\title{
Article
}

\author{
Doi 10.5943/sif/5/1/32
}

\section{Three new records of Cortinarius (Cortinariaceae) for the Turkish Mycota from Trabzon, Turkey}

\author{
Sesli $E^{1 *}$ and Örtücü $S^{2}$ \\ ${ }^{1}$ Trabzon University, Fatih Faculty of Education, Mathematics and Science Education, Department of Biology, \\ Trabzon, Turkey \\ ${ }^{2}$ Erzurum Technical University, High Technology Research and Application Centre, Erzurum, Turkey
}

Sesli E, Örtücü S 2020 - Three new records of Cortinarius (Cortinariaceae) for the Turkish Mycota from Trabzon, Turkey. Studies in Fungi 5(1), 517-525, Doi 10.5943/sif/5/1/32

\begin{abstract}
Basidiomata of Cortinarius were collected during the field studies in 2019 and identified based on both morphological and molecular data. Three Cortinarius species viz. Cortinarius cadiaguirrei, C. cinnamoviolaceus and C. variegatus are recorded for the first time from Turkey. Full descriptions, color figures, a simple phylogenetic tree and a short discussion are provided here.
\end{abstract}

Key words - Agaricales - Basidiomycota - ITS - identification - taxonomy

\section{Introduction}

Interesting Cortinarius species have been described worldwide at recent years. Some new and little known telamonioid Cortinarius species described from Norway by Brandrud et al. (2016). A new conifer-associated, darkening species in the subgenus Telamonia, Cortinarius badiolaevis Niskanen, Liimat., Mahiques, Ballarà, Kytöv. was described from Sweden, Upland, Närke commune, Lillkyrka parish, Ekebergsbrottet in coniferous forest on calcareous soils (Niskanen et al. 2011b). Two new species of Cortinarius, subgenus Telamonia, sections Colymbadini and Uracei, from Europe described by Dima et al. (2014). The largest type study of Agaricales species to date was conducted by Liimatainen et al. (2014). Another important study related with our study is Cortinarius sect. Armillati in northern Europe by Niskanen et al. (2011a). Before the present study, Cortinarius cadi-aguirrei Garrido-Ben., Ballarà \& Mahiques, Cortinarius cinnamoviolaceus M. M. Moser and Cortinarius variegatus Bres. were known from Spain, France and Finland respectively.

Cortinarius cadi-aguirrei Garrido-Ben., Ballarà \& Mahiques was collected and described from Spain, Lleida, Isil and Alòs, Bordesd'Alòs in 2015. It is characterised with slender, relatively small, orange, reddish orange to apricot-like pileus; pale creamy, small stipe and mostly ellipsoid, sometimes slightly amygdaliform basidiospores (Garrido-Benavent et al. 2015). Cortinarius cinnamoviolaceus M. M. Moser was described by Bellanger et al. (2017) from France under Picea abies Karsten in 2012 and is easily distinguished by purple-brown pileus and narrow amygdaliform to ellipsoidal basidiospores. Cortinarius variegatus Bres. was described by Giacopo Bresàdola (Bresadola 1884). In our study, we found Cortinarius cadi-aguirrei, C. cinnamoviolaceus and $C$. variegatus from Turkey for the first time and are described as new records from Turkey. 


\section{Collecting site and morphological description}

The East Black Sea region of Turkey is rainy during whole year, precipitation reaches its maximum in spring and autumn. The annual precipitation shows a significant increase from the west towards the east. On the north coast of Turkey, the differences between summer and winter temperatures are not too much. About $30 \%$ of the region was originally covered by forests. Fagus orientalis Lipsky and Quercus petraea (Mattuschka) Liebl. forests in the west are replaced by Pinus sylvestris L. and Abies bornmuelleriana Mattf. in the East. Picea orientalis (L.) Link becomes dominant above $1000 \mathrm{~m}$. Picea orientalis (L.) Link, Carpinus betulus L., C. orientalis Mill., Castanea sativa Mill., Rhododendron ponticum L., Rh. luteum Sweet, Corylus avellana L. and Alnus glutinosa (L.) Gaertn. are the most common species in the eastern part of the Black Sea coastlands. The alpine biome within the East Black Sea region extends above $2000 \mathrm{~m}$. The Kaçkar Mountains in the east support alpine elements from the Anatolian and Caucasian alpine regions as well as many endemic taxa confined to the East Black Sea region. Dried specimens are deposited in a personal herbarium of Trabzon University, Trabzon, Turkey. Facesoffungi numbers were registered as in Jayasiri et al. (2015).

Basidiomata were collected and photographed from Akçaabat and Maçka districts of Trabzon province of Turkey. Microscopic studies were performed according to Clémençon (2009) in the Mycology Laboratory of Trabzon University. In order to view and examine the basidiospores, a piece of basidioma is placed in 3\% ammoniated water. After waiting for 2-3 minutes, basidiospores were obtained by tightening with the forceps. To view the structure of pileipellis, sections were taken by hand with a razor blade under a Zeiss Stemi 2000-C microscope, and the sections were mounted in $3 \% \mathrm{NH}_{3}$ solution, stained with aqueous 5\% Congo red and examined under a Zeiss Axio Imager A2 trinocular microscope. The images were obtained with the Zeiss Axiocam 105 colour camera, and measurements were made with Imager Software Programme.

\section{DNA extraction, amplification and sequencing}

For the genomic DNA extraction from Cortinarius species, a modified protocol based on that of Murray \& Thompson (1980) was used. Briefly, the pileus context of the dried specimens was blended in CTAB buffer and mixture was incubated for $15 \mathrm{~min}$ at $65^{\circ} \mathrm{C}$. After incubation, an equal volume of chloroform: isoamyl alcohol (24: 1) was added and carefully mixed. It was then centrifuged for $10 \mathrm{~min}$ at the maximum speed, and the DNA in the supernatant was precipitated by isopropanol. After centrifugation at the same speed, the pellet was washed with cold ethanol, centrifuged again and air-dry pellet re-suspended in $\mathrm{ddH}_{2} \mathrm{O}$. Molecular phylogenetic analyses of the Cortinarius species were performed by sequencing of ITS region. The primers used for the polymerase chain reaction (PCR) were ITS1 (TCCGTAGGTGAACCTGCGG) and ITS4 (TCCTCCGCTTATTGATATGC) (White et al. 1990). PCR reactions were carried out in a $50 \mu \mathrm{l}$ reaction volume under the following PCR cycling conditions: one cycle of denaturation at $95^{\circ} \mathrm{C}$ for $5 \mathrm{~min}$, followed by 35 cycles of denaturation at $94^{\circ} \mathrm{C}$ for $45 \mathrm{~s}$, annealing at $54^{\circ} \mathrm{C}$ for $30 \mathrm{~s}$, and elongation at $72^{\circ} \mathrm{C}$ for $45 \mathrm{~s}$ and a final step at $72^{\circ} \mathrm{C}$ for $10 \mathrm{~min}$. PCR products were checked in $1 \%$ $(\mathrm{w} / \mathrm{v})$ agarose gels, and the PCR products purified following the protocols of the Eco Pure PCR/Gel Purification Kit (ECO TECH Biotechnology, Erzurum, TURKEY). After purification, ITS region was sequenced with one or both PCR primers. Sequences chromatograms were checked searching for putative reading errors, which were corrected.

\section{Results}

\section{Sequence alignment and phylogenetic analyses}

Fig. 1

Sequences (Table 1) were assembled into one complete sequence using Bioedit Sequence Alignment Editor Version 7.2.5 (Hall 1999). The sequences were aligned in MEGA-X software (Kumar et al. 2018) with Clustal W and evolutionary analyses were conducted in same software. 
The evolutionary history was inferred by using the Maximum Likelihood method and Tamura-Nei model (Tamura \& Nei 1993) using the standard search algorithm by bootstrap analysis using 1000 replicates. The sequenced PCR amplicons were compared to all known sequences in the GenBank (http://www.ncbi.nlm.nih.gov/) by use of BLASTN 2.10.0+ program (Zhang et al. 2000) and UNITE database (http://unite.ut.ee/). Sequences of three isolates were deposited in the GenBank database under the accession numbers (MT367144, MT367145 and MT367149).

\section{Cortinariaceae R. Heim ex Pouzar}

Cortinarius cadi-aguirrei Garrido-Ben., Ballarà \& Mahiques, Journal des JEC, Journées Européenes du Cortinaire 18(17): 104 (2015)

Fig. 2

Index Fungorum number: IF 816060; Facesoffungi number: FoF 09461

Pileus conical to hemispherical, convex, or dome shaped with a low umbo; reddish brown, reddish purple, orange brown, pale brown or reddish orange; margin paler and the centre typically darker; 10-30 mm, hygrophanous, radially striated up to one third of the centre. Lamellae moderately or rather spaced, adnexed, broad, pale brown, yellowish brown or, cinnamon brown; $\mathrm{L}=$ 30-40, I= 1-3. Stipe cylindrical, larger towards the base, whitish yellow to cream, watery, 30-60 $\times$ 3-5 mm; sometimes the base slightly rounded, fibrous on a pale base, turning pale pink when injured. Universal veil pale cream, scattered in small patches on the stipe surface. Content hygrophanous, pale beige, pale brownish or dark yellowish when dry. Taste and smell indistinct. Basidiospores [ $n=55]$ ellipsoid to slightly amygdaliform, slightly verrucose, granulated, (7.7-)8.59.5 $(-10.5) \times(4.8-) 4.5-5.8(-6) \mu \mathrm{m}$; on average $8.9 \times 5.2 \mu \mathrm{m}, \mathrm{Q}=1.4-1.7, \mathrm{Qm}=1.65$. Basidia clavate, 4-spored, (29-)30-35(-38) × 7.5-9.1 $\mu \mathrm{m}$; on average $32.7 \times 8.6 \mu \mathrm{m}$. Pileipellis consists of incrusted, brownish yellow granulated hyphae. Clamp connections present at all tissues.

Specimen examined - TURKEY, Trabzon, Akçaabat, Fengo plateau, gregarious under spruce (Picea orientalis L.) in extreme wetland, 4055'19.52" N and 39 $24^{\prime} 50.46^{\prime \prime} \mathrm{E}, 1638 \mathrm{~m}$ alt., 28 Oct. 2019, E. Sesli, KATO Fungi 4148.

Cortinarius cinnamoviolaceus M.M.Moser, Nova Hedwigia 14: 514 (1968)

Fig. 3

Index Fungorum number: IF 329008; Facesoffungi number: FoF 09462

Pileus convex to campanulate, almost flat, umbonate, striated until halfway to umbo, 30-70 (-80) mm, hygrophanous, chestnut brown to purplish brown or reddish ocher brown, smooth. Lamellae adnate-uncinate to emarginate, sparse, thick, chocolate-brown to light ochre-brown with a purplish tint and smooth; edge whitish, $\mathrm{L}=20-25$, $\mathrm{I}=1-3$. Stipe cylindrical, tapering and curved towards the base, 70-120 × 5-10 mm, rigid, fibrillose-striated, whitish, silvery with a purplish tint or slightly violet, typically bright. Content dirty white, slightly violet or purplish. Smell raphanoid or slightly iodine. Guaiac with phenol aniline. Basidiospores [ $n=60]$ ovoid to ellipsoid or tonsilliform, smooth, slightly granulated, (8.2-)9-10.8(11.1) $\times(4.6-) 5-6(-6.7) \mu \mathrm{m}$; on average 9.9 $\times 5.6 \mu \mathrm{m}, \mathrm{Q}=1.6-1.8, \mathrm{Qm}=1.76$. Basidia clavate, 4-spored, 35-43 $\times(7-) 8-9(-10) \mu \mathrm{m}$; on average $36.3 \times 8.6 \mu \mathrm{m}$. Marginal cells abundant, filamentous, $(15.1-) 16.7-26(-29.5) \times 6.5-9(-9.5) \mu \mathrm{m}$; on average $22.4 \times 8 \mu \mathrm{m}$. Pileipellis consists of cylindrical to enlarged hyphae. Clamp connections present at all tissues.

Specimen examined- TURKEY, Trabzon, Akçaabat, Fengo plateau, gregarious under spruce (Picea orientalis L.), 4055'22.61" N and 39²5'00.32" E, $1637 \mathrm{~m}$ alt., 28 Oct. 2019, E. Sesli, KATO Fungi 4145.

Cortinarius variegatus Bres., Fung. Trident. 1(4-5): 56 (1884)

Fig. 4

Index Fungorum number: IF 144335; Facesoffungi number: FoF 09463

(Syn. Cortinarius fulvidolilaceus P.D. Orton, Notes R. Bot. Gdn Edinb. 29(1): 90 (1969) = Cortinarius variegatus var. marginatus Bres., Fung. Trident. 1(4-5): 56 (1884) = Gomphos variegatus (Bres.) Kuntze, Revis. Gen. Pl.2: 854 (1891) = Phlegmacium variegatum (Bres.) Ricken ex Gaugue, Docums Mycol. 2(8): 3 (1973) 
Pileus convex, conical to plane with a broad and larger umbo, fleshy, covered with a slimy gel, fibrillose, surface, excessively sticky, reddish brown, pinkish brown to pale brown, darker at the centre and lighter towards the edge; margin sometimes spitted, 70-100 mm. Content whitish. Lamellae initially whitish, then pale yellowish to cinnamon, darker over time, smooth, adnate to sinuate. Stipe cylindrical, larger towards the base, curved, fibrillose, whitish, subferruginous, marginato-bulbosus, wiolet to purplish from place to place, covered with a whitish cottony mycelium towards base; 50-70 × 20-30 mm. Basidiospores [ $\mathrm{n}=50$ ] subamydaliformis, (6.9-)7.5$9(-10.1) \times(2.8-) 3-3.8(-4.2) \mu \mathrm{m}$; on average $8.5 \times 3.5 \mu \mathrm{m}$. Basidia clavate, $24-28 \times 6.6-7.7(-8)$ $\mu \mathrm{m}$; on average $26.1 \times 6.7 \mu \mathrm{m}$. Pileipellis made up of cylindrical and regular hyphae. Clamp connections present.

Specimen examined- TURKEY, Trabzon, Akçaabat, Fengo plateau, gregarious with Picea orientalis L., 4055'29.39" N and 39²4'29.61" E, 1540 m alt., 28 Sept. 2019, E. Sesli, KATO Fungi 4128.

Table 1 Taxa names, strains, and GenBank numbers of the taxa used in the phylogenetic analyses

\begin{tabular}{|c|c|c|c|c|}
\hline Taxa names & Strain/Voucher & Database & ID & References \\
\hline $\begin{array}{l}\text { Cortinarius cadi- } \\
\text { aquirrei }\end{array}$ & 4148 & GenBank & MT367144 & This study \\
\hline C. cadi-aguirrei & JB-3089/98 & GenBank & KJ866953 & $\begin{array}{l}\text { (Garrido-Benavent } \\
\text { et al. 2014) }\end{array}$ \\
\hline C. cinnamoviolaceus & 4145 & GenBank & MT367145 & This study \\
\hline C. cinnamoviolaceus & $\begin{array}{l}\text { A. Bidaud 02-10- } \\
71\end{array}$ & GenBank & KX964418 & $\begin{array}{l}\text { (Liimatainen et al. } \\
\text { 2017) }\end{array}$ \\
\hline C. variegatus & 4128 & GenBank & МT367149 & This study \\
\hline C. variegatus & $\begin{array}{l}\text { J. Ballara: JB- } \\
8061 / 13\end{array}$ & GenBank & KY657262 & (Ballara et al. 2017) \\
\hline C. variegatus & AK457 & UNITE & UDB020288 & - \\
\hline C. aureopigmentatus & $\begin{array}{l}\text { USJ J.F. } \\
\text { Ammirati } 11940\end{array}$ & GenBank & NR_131794 & $\begin{array}{l}\text { (Ammirati et al. } \\
\text { 2007) }\end{array}$ \\
\hline C. savegrensis & $\begin{array}{l}\text { USJ J.F. } \\
\text { Ammirati } 11950\end{array}$ & GenBank & NR_131797 & $\begin{array}{l}\text { (Ammirati et al. } \\
\text { 2007) }\end{array}$ \\
\hline C. ovreboi & $\begin{array}{l}\text { USJ J.F. } \\
\text { Ammirati } 13000\end{array}$ & GenBank & NR_131801 & $\begin{array}{l}\text { (Ammirati et al. } \\
\text { 2007) }\end{array}$ \\
\hline C. borgsjoensis & S F44794 & GenBank & NR_130196 & $\begin{array}{l}\text { (Liimatainen et al. } \\
\text { 2014) }\end{array}$ \\
\hline C. hedyaromaticus & $\begin{array}{l}\text { MONT C. Cripps } \\
\text { CLC316 }\end{array}$ & GenBank & NR_153046 & (Cripps et al. 2015) \\
\hline C. hirtipes & $\begin{array}{l}\text { PC P. Moenne- } \\
\text { Locc. PML362 }\end{array}$ & GenBank & NR_153066 & $\begin{array}{l}\text { (Niskanen et al. } \\
\text { 2016) }\end{array}$ \\
\hline C. elegantio-montanus & IB19890059 & GenBank & GU363473 & $\begin{array}{l}\text { (Garnica et al. } \\
\text { 2011) }\end{array}$ \\
\hline C. furvolaesus & CFP517 & GenBank & DQ139986 & $\begin{array}{l}\text { (Kytovuori et al. } \\
\text { 2005) }\end{array}$ \\
\hline C. caperatus & HMJAU: 44243 & GenBank & MH295810 & - \\
\hline C. armillatus & S F256861 & GenBank & NR_131891 & $\begin{array}{l}\text { (Kytovuori et al. } \\
\text { 2005) }\end{array}$ \\
\hline C. kula & MEL2089691 & GenBank & JX679114 & (Stefani et al. 2014) \\
\hline C. violaceus & NY: 401880 & GenBank & KJ920068 & $\begin{array}{l}\text { (Harrower et al. } \\
\text { 2015) }\end{array}$ \\
\hline
\end{tabular}

* Sequences produced from this study are in black bold 


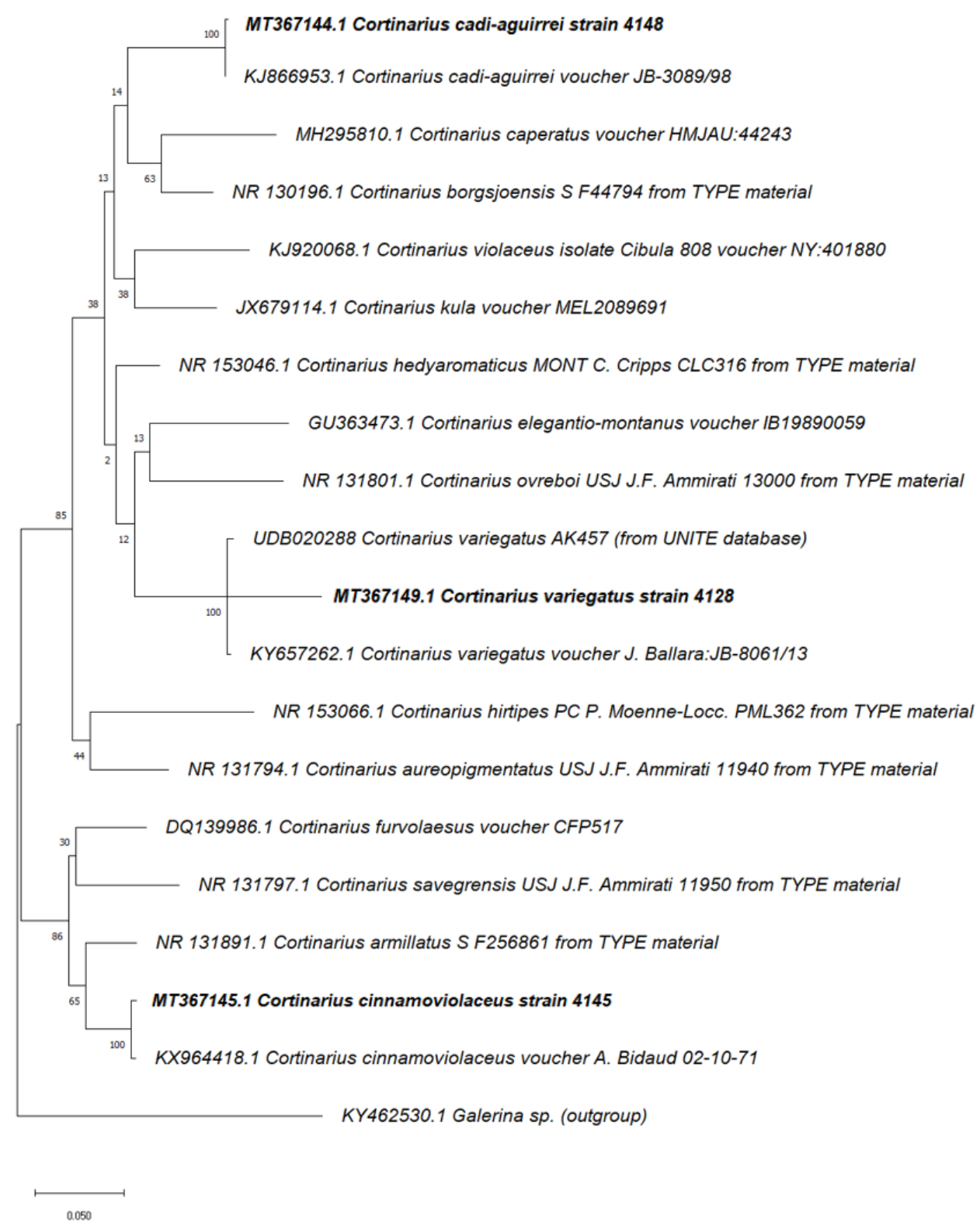

Fig. 1 - Phylogenetic relationship of present study ITS sequences by Maximum Likelihood method. The tree with the highest log likelihood (-4511.53) is shown. The percentage of trees in which the associated taxa clustered together is shown next to the branches. Initial tree(s) for the heuristic search were obtained automatically by applying Neighbor-Join and BioNJ algorithms to a matrix of pairwise distances estimated using the Tamura-Nei model, and then selecting the topology with superior log likelihood value. The tree is drawn to scale, with branch lengths measured in the number of substitutions per site. This analysis involved 20 nucleotide sequences. There were a total of 834 positions in the final dataset. Galerina sp. was used as outgroup.

\section{Key to Cortinariusspecies}

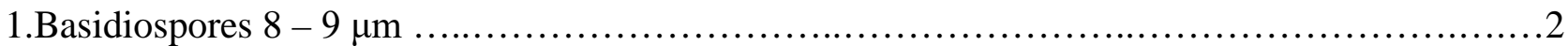

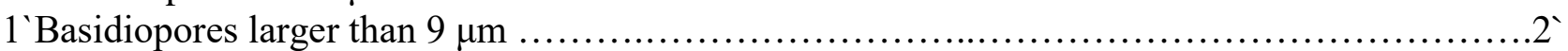

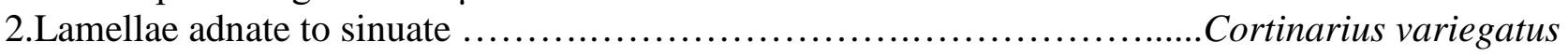

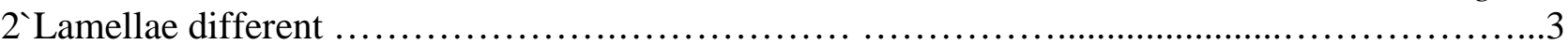

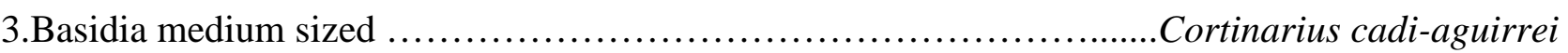

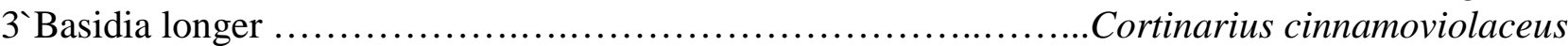




\section{Discussion}

Cortinarius cadi-aguirrei, C. cinnamoviolaceus and C. variegatus are recorded for the first time from Turkey and provided here with descriptions, field and microscopic photos and a phylogenetic tree. Our results about the new records generally matched very well with the original descriptions. Findings connected with Cortinarius cadi-aguirrei by Garrido-Benavent et al. (2015) (10-40 mm, orange, reddish orange to apricot-like orange pileus, 40-70 $\times 4-7 \mathrm{~mm}$, pale brownish stipe, 8-10.5 × 4.5-5.5 $\mu \mathrm{m}$, mostly ellipsoid, sometimes slightly amygdaliform basidiospores) fit well with KATO Fungi 4148.

Another species collected from Trabzon (KATO Fungi 4145) is the same with Cortinarius cinnamoviolaceus described by Bellanger et al. (2017). According to the other morphological and molecular evaluations, we think that the reason for some small differences are due to the different ecological conditions.
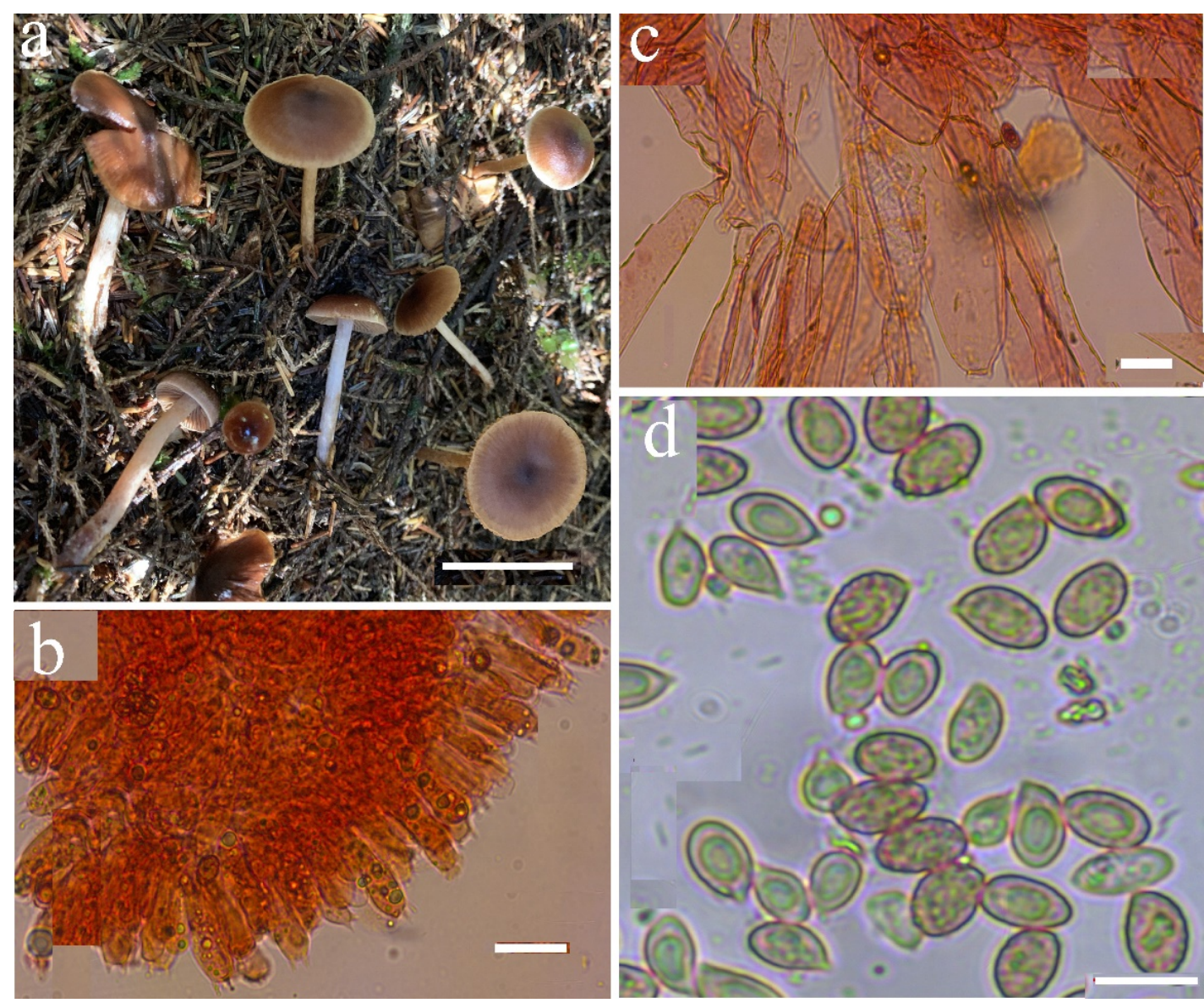

Fig. 2 - Cortinarius cadi-aguirrei. a basidiomata. b basidia. c pileipellis. d basidiospores. Scale bars: $\mathrm{a}=30 \mathrm{~mm}, \mathrm{~b}, \mathrm{c}=20 \mu \mathrm{m}, \mathrm{d}=10 \mu \mathrm{m}$.

Cortinarius variegatus described by Bresadola (1884) is highly compatible with our findings (KATO Fungi 4128). The molecular characterization was performed by carrying out sequencing of rDNA ITS region. In this study, the ITS region (ITS1-5.8S-ITS2) amplified with ITS1 and ITS4 pair of primers varied in length from 580 to $618 \mathrm{bp}$ in the three species. The ITS sequences were compared to all known sequences in the GenBank for confirmation of their identity. Based on percentage identity and query coverage, the three Cortinarius species identified as follows: accession MT367144 showed 99\% identity with C. cadi-aguirrei (KJ866953.1; 100\% coverage); MT367145 showed 99\% identity with C. cinnamoviolaceus (KX964418.1; 99\% coverage) and MT367149 showed 97\% 99\% identity with C. variegatus (KY657262.1; 92\% coverage, UDB020288; 99\% coverage respectively). These three species were identified up to species level from the GenBank database. In this study, we used a combined approach with morphological and 
molecular analysis of Cortinarius species. This approach has proven very useful and valuable tool for correct identification. Some authors have also used ITSr DNA sequences combination with morphological characters for identification of Cortinarius species (Peintner et al. 2003, Becerra et al. 2005, Itoo et al. 2015, Sesli \& Liimatainen 2018, Şengül Demirak et al. 2020).

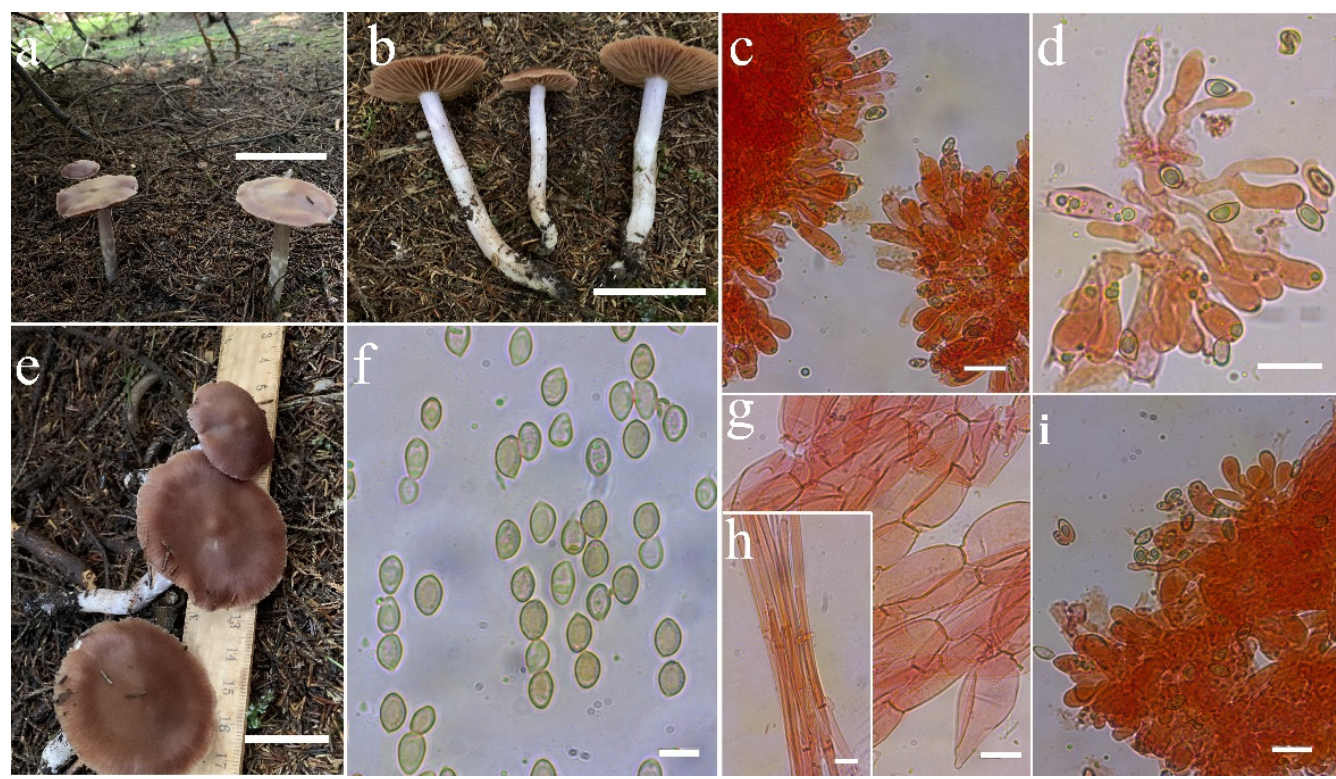

Fig. 3 - Cortinarius cinnamoviolaceus. a, b, e basidiomata. c, d, i basidia and marginal cells. g, h pileipellis. Scale bars: a, b = $70 \mathrm{~mm}, \mathrm{e}=35 \mathrm{~mm}, \mathrm{c}, \mathrm{d}, \mathrm{g}, \mathrm{i}=20 \mu \mathrm{m}, \mathrm{h}=10 \mu \mathrm{m}$.

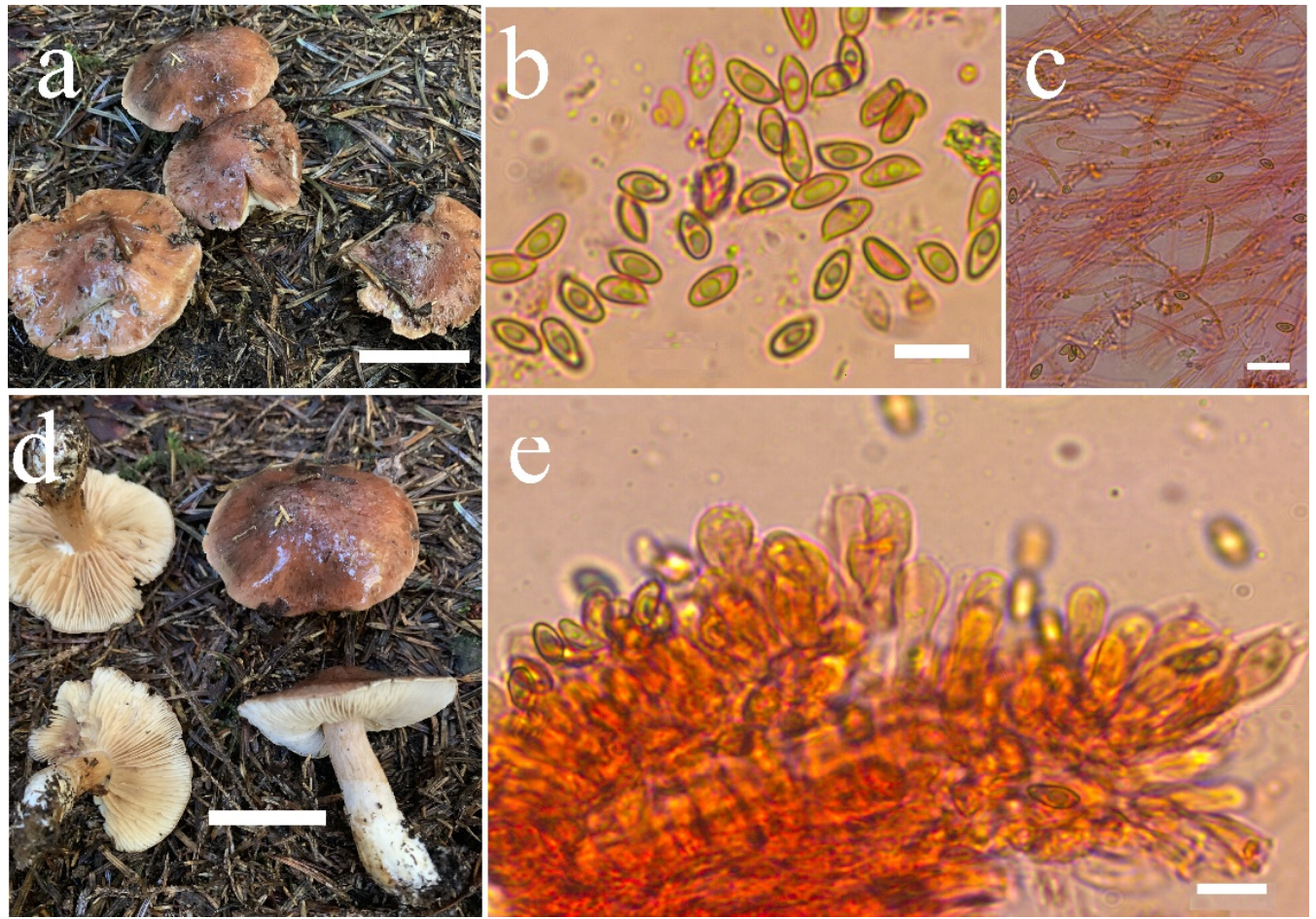

Fig. 4 - Cortinarius variegatus. a, d basidiomata. b basidiospores. c pileipellis. e basidia. Scale bars: a, $\mathrm{d}=50 \mathrm{~mm}, \mathrm{~b}, \mathrm{e}=10 \mu \mathrm{m}, \mathrm{c}=20 \mu \mathrm{m}$.

Currently, 15843 records in the GenBank and 2064 records in the UNITE database are available for Cortinarius genus. As the available data increases, it is more possible to solve identification in the Cortinarius genus (Şengül Demirak et al. 2020). Our ITSr DNA data may contribute to the correct identification of Cortinarius species and related taxa. 


\section{Acknowledgements}

This work was financed by the Trabzon University (TAP: 20TAP00123). The first author would like to thank Dr. Kare Liimatainen for his comments about the sequences.

\section{References}

Ammirati J, Garnica S, Halling RE, Mata M et al. 2007 - New Cortinarius species associated with Quercus and Comarostaphylis in Costa Rica. Canadian Journal of Botany 85, 794-812.

Ballara J, Mahiques R, Garrido-Benavent I. 2017 - Estudi de Cortinariaceae del Parc. Natural CadiMoixero (IV). Moixero 9, 20-49.

Becerra A, Beenken L, Pritsch K, Daniele G et al. 2005 - Anatomical and molecular characterization of Lactarius aff. omphaliformis, Russula alnijorullensis and Cortinarius tucumanensis ectomycorrhizae on Alnus acuminata. Mycologia 97, 1047-1057.

Bellanger JM, Carteret X, Bidaud A. 2017 - Cortinarius cinnamoviolaceus, l'espèce "Canada dry”, in Paz Conde \& Lavoise. Myco-Liebana 73-80.

Brandrud TE, Bendiksen E, Dima B. 2016 - Some new and little known telamonioid Cortinarius species from Norway. Agarica 36, 11-42.

Bresadola G. 1884 - Cortinarius variegatus Bres. Fungi Tridentini 1, 43-70.

Clémençon H. 2009 - Methods for Working with Macrofungi: Laboratory Cultivation and Preparation of Larger Fungi for Light Microscopy. Berchtesgadener Anzeiger, Germany.

Cripps CL, Liimatainen K, Niskanen T, Dima B et al. 2015 - Intercontinental distributions of species of Cortinarius, subgenus Phlegmacium, associated with Populus in western North America. Botany 93(11), 711-721.

Dima B, Liimatainen K, Niskanen T, Kytövuori I, Bojantchev D. 2014 - Two new species of Cortinarius, subgenus Telamonia, sections Colymbadini and Uracei, from Europe. Mycological Progress 13, 867-879.

Garnica S, Spahn P, Oertel B, Ammirati J, Oberwinkler F. 2011 - Tracking the evolutionary history of Cortinarius species in section Calochroi, with transoceanic disjunct distributions. BMC Evolutionary Biology 11(1), 213.

Garrido-Benavent I, Ballara J, Mahiques R. 2014 - Cortinarius cadi-aguirrei, un noutaxon de la seccio Fulvescentes Melot. Journal des Journées Européennes du Cortinaire16, 24 - 34.

Garrido-Benavent I, Ballará J, Mahiques R.2015 - Cortinarius cadi-aguirrei, a new taxon of the section Fulvescentes Melot. Journal des J.E.C. 17, 102-107.

Hall TA. 1999 - BioEdit: a user-friendly biological sequence alignment editor and analysis program for Windows 95/98/NT. Nucleic Acids Symposium Series 41, 95-98.

Harrower E, Bougher NL, Henkel TW, Horak E, Matheny PB. 2015 - Long-distance dispersal and speciation of Australasian and American species of Cortinarius sect. Cortinarius. Mycologia 107(4), 697-709.

Itoo ZA, Reshi ZA, Basharat Q, Majeed ST, Andrabi KI. 2015 - Identification and characterization of ectomycorrhizal Cortinarius species (Agaricales, Basidiomycetes) from Temperate Kashmir Himalaya, India, by ITS Barcoding. Advances in Molecular Biology 507684, 1-9.

Jayasiri SC, Hyde KD, Ariyawansa HA, Bhat J et al. 2015 - The Faces of Fungi database: fungal names linked with morphology, phylogeny and human impacts. Fungal diversity, 74(1), 318.

Kumar S, Stecher G, Li M, Knyaz C, Tamura K. 2018 - MEGA X: Molecular evolutionary genetics analysis across computing platforms. Molecular Biology \& Evolution 35, 15471549.

Kytovuori I, Niskanen T, Liimatainen K, Lindstrom HK. 2005 - Cortinarius sordidemaculatus and two new related species, C. anisatus and C. neofurvolaesus, in Fennoscandia (Basidiomycota, Agaricales). Karstenia 45(1), 33-50. 
Liimatainen K, Niskanen T, Dima B, Kytövuori I et al. 2014 - The largest type study of Agaricales species to date: bringing identification and nomenclature of Phlegmacium (Cortinarius) into the DNA era. Persoonia 33, 98-140.

Liimatainen K, Carteret X, Dima B, Kytovuori I et al. 2017 - Cortinarius section Bicolores and section Saturnini (Basidiomycota, Agaricales), a morphogenetic overview of European and North American species. Persoonia 39, 175-200.

Murray MG, Thompson WF. 1980 - Rapid isolation of high molecular weight plant DNA. Nucleic Acids Research 8, 4321-4325.

Niskanen T, Kytövuori I, Liimatainen K. 2011a - Cortinarius sect. Armillati in Northern Europe. Mycologia 103, 1080-1101.

Niskanen T, Liimatainen K, Mahiques R, Ballarà J, Kytövuori I. 2011b - Cortinarius badiolaevis, a new conifer-associated, darkening species in the subgenus Telamonia (Basidiomycota, Agaricales) Mycological Progres 10, 101-105.

Niskanen T, Liimatainen K, Kytovuori I, Lindstrom H et al. 2016 - Cortinarius subgenus Callistei in North America and Europe-type studies, diversity, and distribution of species. Mycologia 108(5), 1018-1027.

Peintner U, Moser MM, Thomas KA, Manimohan P. 2003 - First records of ectomycorrhizal Cortinarius species (Agaricales, Basidiomycetes) from tropical India and their phylogenetic position based on rDNA ITS sequences. Mycological Research 107, 485-494.

Stefani FOP, Jones RH, May TW. 2014 - Concordance of seven gene genealogies compared to phenotypic data reveals multiple cryptic species in Australian dermocyboid Cortinarius (Agaricales). Molecular Phylogenetics and Evolution 71, 249-260.

Sesli E, Liimatainen K. 2018 - Cortinarius conicoumbonatus (Cortinarius subgen. Telamonia sect. Hinnulei): a new species from spruce-beech forests of the East Black Sea Region of Turkey. Turkish Journal of Botany 42, 327-334.

Şengül Demirak MŞ, Işık H, Türkekul İ. 2020 - Morphological and Molecular Phylogeny of Cortinarius rufo-olivaceus (Pers.) Fr. (subgenus Phlegmacium sect. Calochroi) collected from Tokat region. Kahramanmaraş Sütçü İmam Üniversitesi Tarım ve Doğa Dergisi 23, 600-605.

Tamura K, Nei M. 1993 - Estimation of the number of nucleotide substitutions in the control region of mitochondrial DNA in humans and chimpanzees. Molecular Biology and Evolution 10, 512-526.

White TJ, Bruns TD, Taylor LJ. 1990 - Amplification direct sequencing of fungal ribosomal RNA genes for phylogenetics. In: Innis MA, Gelf DH, Sninsky JJ, White TJ (eds). PCR Protocols: A Guide to Methods Applications. Academic Press, New York, pp. 315-322.

Zhang Z, Schwartz S, Wagner L, Miller W. 2000 - A greedy algorithm for aligning DNA sequences. Journal of Computational Biology 7, 203-214. 